\title{
Hybrid Qualifications
}

Structures and Problems in the Context of European vet policy

Jørgensen, Christian Helms; Deissinger, Thomas ; Aff, Josef ; Fuller, Alison

\section{Publication date:}

2013

\section{Document Version}

Early version, also known as pre-print

Citation for published version (APA):

Jørgensen, C. H., Deissinger, T., Aff, J., \& Fuller, A. (Eds.) (2013). Hybrid Qualifications: Structures and Problems in the Context of European vet policy. Peter Lang. Studies in Vocational and Continuing Education Vol. 10

\section{General rights}

Copyright and moral rights for the publications made accessible in the public portal are retained by the authors and/or other copyright owners and it is a condition of accessing publications that users recognise and abide by the legal requirements associated with these rights.

- Users may download and print one copy of any publication from the public portal for the purpose of private study or research. - You may not further distribute the material or use it for any profit-making activity or commercial gain.

- You may freely distribute the URL identifying the publication in the public portal.

\section{Take down policy}

If you believe that this document breaches copyright please contact rucforsk@kb.dk providing details, and we will remove access to the work immediately and investigate your claim. 


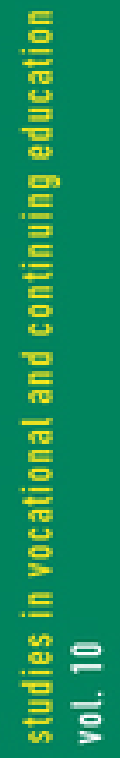

\section{hybrid qualifications: structures and problems in the context of european vet policy}

thomas deissinger. josef aff, alison fuller \& christian helms jergensen (eds) 


\section{Table of Contents}

Preface by the editors $\ldots \ldots \ldots \ldots \ldots \ldots \ldots \ldots \ldots \ldots$

\section{Part One}

Findings from the Leonardo Innovation Transfer

Project "Hybrid Qualifications - increasing the value

of Vocational Education and Training in the context

of Lifelong Learning"

JOSEF AFF, ELISABETH PASCHINGER

\& JOHANNA RECHBERGER

The realisation of hybrid qualifications in Austria -

structures, analysis, empirical findings .......... 13

Christian Helms JøRGENSEN

Linking the dual system with higher education

in Denmark - when strength becomes weakness ........ 53

GAYNA DAVEY \& ALISON FulleR

Transcending the academic-vocational binary

in England? - An exploration of the promise

of hybrid qualifications $\ldots \ldots \ldots \ldots \ldots \ldots \ldots \ldots$

THOMAS DEISSINGER, ROLAND WERN,

ROBIN HEINE \& MARISKA OTT

Progression from VET into higher education via

hybrid qualifications in Germany: context - policy -

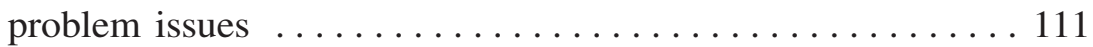


Part Two

Hybrid Qualifications in and outside Europe

DAVID RAFFE \& CATHY HOWIESON

Hybrid qualifications in a credit-based system:

Scottish Higher National Certificates and Diplomas . . . . . 149

ALISON TAYLOR, BONNIE WATT-MALCOLM

\& RANDOLPH WIMMER

'Hybridity' in two Canadian provinces:

Blurring institutional boundaries $\ldots \ldots \ldots \ldots \ldots \ldots \ldots$

PHILIPP GONON

Federal Vocational Baccalaureate: The Swiss way

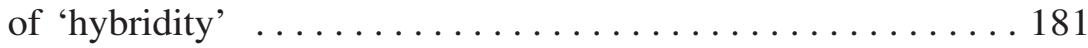

PHILIPPE MÉHAUT

Hybrid or dual currency qualifications? - The French case . . 197

JEROEN ONSTENK

Hybrid qualifications in the Netherlands:

Vocational educational pathways into higher education

as an obstacle course ....................... 213

ERICA SMITH

'Qualifications for work and further learning':

The Australian approach to hybrid qualifications

\section{Part Three}

Thomas Deissinger, Josef AfF, Alison Fuller

\& Christian H. JøRGENSEN

Policy Implications and Recommendations:

When do hybrid qualifications work and what benefits

can be expected from them? ................. 243

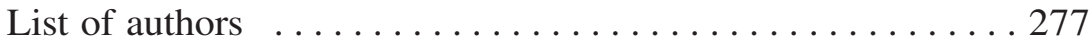

